\title{
Course-Based Undergraduate Research Experiences Can Make Scientific Research More Inclusive
}

\author{
Gita Bangera* ${ }^{* \dagger}$ and Sara E. Brownell ${ }^{\dagger \ddagger}$
}

\author{
*Bellevue College, Bellevue, WA 98007; `School of Life Sciences, Arizona State University, Tempe, AZ 85287
}

Submitted June 14, 2014; Revised August 27, 2014; Accepted August 27, 2014

Monitoring Editor: Graham Hatfull

The U.S. scientific research community does not reflect America's diversity. Hispanics, African Americans, and Native Americans made up $31 \%$ of the general population in 2010 , but they represented only 18 and $7 \%$ of science, technology, engineering, and mathematics (STEM) bachelor's and doctoral degrees, respectively, and 6\% of STEM faculty members (National Science Foundation [NSF], 2013). Equity in the scientific research community is important for a variety of reasons; a diverse community of researchers can minimize the negative influence of bias in scientific reasoning, because people from different backgrounds approach a problem from different perspectives and can raise awareness regarding biases (Intemann, 2009). Additionally, by failing to be attentive to equity, we may exclude some of the best and brightest scientific minds and limit the pool of possible scientists (Intemann, 2009). Given this need for equity, how can our scientific research community become more inclusive?

Current approaches to improving diversity in scientific research focus on graduating more STEM majors, but graduation with a STEM undergraduate degree alone is not sufficient for entry into graduate school. Undergraduate independent research experiences are becoming more or less a prerequisite for admission into graduate school and eventually a career in academia; a quick look at the recommendations for any of the top graduate programs in biology or science career-related websites state an expectation for undergraduate research and a perceived handicap if recommendation letters for graduate school do not include a discussion of the applicant's research experience (Webb, 2007; Harvard University, 2013).

DOI: $10.1187 /$ cbe.14-06-0099

Address correspondence to: Gita Bangera (gita.bangera@ bellevuecollege.edu).

${ }^{+}$The authors contributed equally to this work.

(C) 2014 G. Bangera and S. E. Brownell. CBE-Life Sciences Education (C) 2014 The American Society for Cell Biology. This article is distributed by The American Society for Cell Biology under license from the author(s). It is available to the public under an AttributionNoncommer-cial-Share Alike 3.0 Unported Creative Commons License (http:/ / creativecommons.org/licenses/by-nc-sa/3.0).

"ASCB ${ }^{\circledR}$ " and "The American Society for Cell Biology ${ }^{\circledR}$ " are registered trademarks of The American Society for Cell Biology.
Independent undergraduate research experiences have been shown to improve the retention of students in scientific research (National Research Council, 2003; Laursen et al., 2010; American Association for the Advancement of Science, 2011; Eagan et al., 2013). Participation in independent research experiences has been shown to increase interest in pursuing a PhD (Seymour et al., 2004; Russell et al., 2007) and seems to be particularly beneficial for students from historically underrepresented backgrounds (Villarejo et al., 2008; Jones et al., 2010; Espinosa, 2011; Hernandez et al., 2013). However, the limited number of undergraduate research opportunities available and the structure of how students are selected for these independent research lab positions exclude many students and can perpetuate inequities in the research community. In this essay, we highlight barriers faced by students interested in pursuing an undergraduate independent research experience and factors that impact how faculty members select students for these limited positions. We examine how bringing research experiences into the required course work for students could mitigate these issues and ultimately make research more inclusive.

\section{BARRIERS FOR STUDENTS}

In the following sections, we discuss a few of the barriers faced by undergraduates who are interested in pursuing these undergraduate independent research experiences, hurdles that may restrict research opportunities to select groups of people.

\section{Awareness of Existing Research Opportunities}

For students to participate in independent research experiences, they must first be aware that such opportunities exist. It has been shown that few students are aware of the research aspects of universities when they apply to college (Healey et al., 2010) or in their introductory years (Spronken-Smith et al., 2013). It is likely that students at community colleges or primarily teaching institutions are often unaware of such opportunities, because these research experiences may not exist at their own institutions. As more than 
$50 \%$ of students nationwide begin their studies at a community college and a higher percentage of these students are from lower socioeconomic groups and/or members of historically underrepresented groups (Teacher Advisory Council, 2012), this impacts a significant population of students who could contribute to making the scientific community more diverse. Even students at institutions with extensive research infrastructures may not be aware of the research opportunities available to them if the opportunities are not advertised broadly or effectively.

\section{Awareness of the Possible Benefits of Research Experiences}

Students, particularly first-generation students, and their families may be unaware of the benefits of undergraduate research: the spectrum of different skills and knowledge they can gain, the networking possibilities, or the fact that an immersive research experience could be a defining feature of their undergraduate studies. This lack of cultural capital-knowledge, skills, and education that a person has that give him or her a higher status in society (Bourdieu, 1986)—can be an impediment to students becoming involved in undergraduate research. This can stem from the family: if a student's parents do not have the knowledge that undergraduate research is an important step toward a career in science, then students may not acquire that knowledge. As a result, undergraduate research may not be prioritized and may even be viewed as a distraction in a student's undergraduate studies. Thus, background inequities related to first-generation status can be converted into differential academic achievement, perpetuating inequities in society (Bourdieu, 1986; Adamuti-Trache and Andres, 2008).

\section{Awareness of Cultural Norms Associated with Scientific Research}

Cultural norms of scientific research are also barriers, because the rules are often not made explicit to students (Carlone and Johnson, 2007). The process of finding an independent research experience is often left to the student with few instructions from faculty. For example, many of these independent research experiences are obtained through informal interactions with a faculty member (Seymour et al., 2004; Eagan et al., 2011a,b), but this may not be widely known to students. Some of these implicit norms include knowledge about procedures (e.g., How do I find an opportunity in a research lab?), knowledge about financial or academic gains (e.g., Can I get paid to do research? Can I earn course credit for doing research?), knowledge about social interactions (e.g., What should an email to a faculty member include? Is it okay to email a faculty member I have never met?), and knowledge about organizational structures of research labs (e.g., What is a postdoc?). The students who have access to this knowledge-which likely stems from cultural capital—will have an advantage (Bourdieu, 1986).

\section{Perceived Barriers to Interactions with Faculty}

Even if students understand the cultural norms, they may perceive barriers in making contact with faculty. For most undergraduate independent research experiences, students need to take the initiative to contact faculty members or apply for programs. Students who do not personally know researchers in their own family or community may not consider research an option for themselves. Studies have shown that some students, particularly students of color, may feel a disconnect between themselves and faculty, which may in turn prevent them from approaching professors, especially in their introductory years (Shehab et al., 2007; Hurtado et al., 2011). STEM faculty members have been described by students as "cool," "intimidating," and "unapproachable" (Seymour and Hewitt, 1997; Vogt, 2008), which may be why most undergraduate students do not interact frequently with faculty (Cotten and Wilson, 2006; Cox and Orehovec, 2007). It has been shown that students from upper-class families or whose parents went to college are more likely than students from lower- or middle-class families or first-generation students to assist faculty with research for course credit and communicate with faculty by email or in person (Kim and Sax, 2009), indicating that there are nonacademic differences that impact making contact with faculty.

Taking the initiative to contact faculty in order to participate in an independent research experience may be particularly problematic for students who have less confidence in their own abilities, because these students may be intimidated by faculty (Kuh et al., 2005; Cotten and Wilson, 2006) or unsure of how to initiate these discussions (Vianden, 2006). Gender differences in confidence have been shown at the K-12 level even after controlling for actual academic ability (Meece et al., 2006; Micari et al., 2007; Sikora and Pokropek, 2012); this may contribute to female students not feeling confident enough in their own abilities to apply for these independent research experiences.

\section{Financial and Personal Barriers}

Many research experiences begin as volunteer opportunities, which often lead to paid positions. However, students from lower socioeconomic classes often must work to finance their college studies and thus may be unable to volunteer for a research experience. In fact, student debt has been shown to decrease the likelihood that a student will pursue graduate training in STEM (Malcom and Dowd, 2012), and financial inability to volunteer for an undergraduate research experience may contribute to this problem. Even the NSF Research Experiences for Undergraduates program, which provides housing and a stipend, may be inaccessible for nontraditional students supporting a family or for students who cannot leave their homes/communities for an entire summer.

In sum, these hurdles disproportionately filter out first-generation students, women, and groups historically underrepresented in science, thus reducing the diversity of the pool of students who apply to these independent research experiences.

\section{FACTORS THAT IMPACT FACULTY SELECTION OF STUDENTS FOR INDEPENDENT RESEARCH EXPERIENCES}

In addition to these barriers that diminish student participation, conflicting demands faced by principal investigators of independent research labs may also exacerbate inequities. 
The mission of universities is to integrate teaching and research, thus contributing to expanding the knowledge base and producing a highly skilled next generation of citizens. However, the reward structure for principal investigators often does not mirror these larger institutional goals (Boyer, 1990; Wilson, 2010; Brownell and Tanner, 2012). Arguably, given the current reward structure, the primary function of a research lab is to produce novel results, with a secondary function of training the next generation of scientists. Pressure to publish high-impact science while securing competitive funding can put principal investigators of research labs in an untenable situation wherein they must balance research and mentoring needs, and mentoring often suffers in favor of research.

\section{Assessment of Mentorship and Preference for the "Best" Students}

While mentoring is usually required of faculty, its effectiveness is often measured by examining the total number of mentees and how successful the mentees were in their subsequent scientific careers. By examining only the final products instead of the gains from or value added by the experience, faculty members may be pressured to select students with pre-existing backgrounds that will make them strong candidates for subsequent success in research. Without knowing what metrics best predict research success, faculty members fall back on metrics such as grade point average (GPA), prior research experience, or interviewing skills to evaluate applicants; the students who rise to the top of this pool tend to be high performers (e.g., have high GPAs), have prior research experience (e.g., did research in high school), and may already know about the culture of research (e.g., what questions to ask in the interview). Whether these metrics predict student success in undergraduate research or whether they merely sustain inequities in the system is yet to be determined.

However, this "rising star hypothesis" suggests that faculty members prefer students who are predicted to be stars-students who demonstrate motivation, achievement, and a proactive career orientation (Ragins and Cotton, 1993; Wanberg et al., 2003; Eagan et al., 2011b). Those students who enter college with higher academic preparation tend to be selected by faculty to be mentored (Terenzini and Pascarella, 1978; Chapman and Pascarella, 1983). The problem with this way of selecting students is that it eliminates from the pool students who may come from cultures that do not emphasize self-promotion in education or who arrive at college with lower levels of academic preparation (Ragins, 1999; Eagan et al., 2011b). Thus, the current system's structure is such that there is limited incentive for faculty members to take risks by selecting underperforming, shy, or modest students with potential, thereby excluding students who may be capable of making significant contributions to a research program.

\section{Unconscious Societal Bias}

Societal biases that trickle down into hiring decisions for independent research experiences further impact the diversity of students entering research. Research on racial discrimination in the job market has shown that résumés with names perceived to be white were $50 \%$ more likely to be hired than résumés with names perceived to be African American (Bertrand and Mullainathan, 2003), and faculty members have a higher probability of responding to emails from a student with a name perceived to be white (Milkman et al., 2014). It has also been shown that male and female science faculty members were more likely to hire male research assistants, mentor them more, and pay them a higher salary (Moss-Racusin et al., 2012). These likely unconscious biases lead to greater exacerbation of inequities during the selection process via a preference for white males.

This exclusion at the first entry point to research has critical consequences, as research experience is an essential part of the application to graduate school. In fact, most graduate programs and even some internship programs now require multiple years of research experience as a prerequisite. Inequities at this initial phase set in motion an uphill battle for students that culminates in inequities in graduate school, postdoctoral training, and beyond.

\section{A CURE FOR INEQUITY?}

A solution to this bottleneck is to restructure the first entry point into research. Instead of being required to apply and be selected for independent research experiences, students could enroll in courses that provide them with an opportunity to engage in authentic research and earn course credit. These course-based undergraduate research experiences, or CUREs, have the potential to give all students, rather than only a select few, the opportunity to engage in research. Although CUREs by their very nature are diverse in structure and theme, they are defined as having the following five elements that are reflective of authentic research: 1) engaging students in scientific practices; 2) emphasizing collaboration; 3) examining broadly relevant topics; 4) exploring questions with unknown answers to expose students to the process of scientific discovery; and 5) integrating iteration into the course, so students can see how science builds on itself (Auchincloss et al., 2014). CUREs are often presented as a solution to the limited number of positions available in independent research labs (Desai et al., 2008), but we argue that the most important function of a CURE could be to make the research community more inclusive. We argue that providing CUREs to students is an effective way to introduce students of varying backgrounds to research, thereby potentially broadening the diversity of the scientific community.

\section{CUREs Need to Be Required Introductory-Level Courses}

If CUREs were made required introductory courses, they would help reduce the factors that contribute to inequities and give all students the opportunity to engage in authentic research. Students enroll in CUREs like any other course; students do not need to be aware of unique opportunities, consider whether the course will be beneficial, or need any additional insight into the culture of science. Students earn course credit and do not have to volunteer for the experience. The course instructor is free of the conflicts faced by principal investigators; the instructor is responsible for teaching students rather than producing a publishable unit. By giving all students these opportunities, CUREs level the playing field for students interested in exploring independent research. 
For primarily teaching institutions with limited independent research opportunities, such as community colleges, CUREs can provide students with the opportunity to perform authentic research and better equip them to apply for independent research experiences at their transfer institutions. CUREs are currently being implemented in these environments; one of the authors (G.B.) developed and/or taught multiple CUREs at her community college and is currently training other instructors at 14 different community colleges to teach these courses at the introductory level.

Is it possible to offer this type of introductory research-intensive course to students on a large scale? Recently, Stanford University redesigned its introductory biology lab courses to convert them to CUREs that are required for all biology majors, with class sizes scaling up to more than 250 students, indicating that it is possible to do this as a required course on a large scale (Brownell et al., 2013). Other similar high-enrollment models exist, including a CURE at Boston College (CUREnet, 2012).

While the majority of published accounts of CUREs are for smaller, upper-level courses, the recent Howard Hughes Medical Institute university competition specifically called for efforts to broaden the participation of students in research in their introductory years, so we expect to see a greater number of high-enrollment introductory CUREs in the coming years. In fact, for CUREs to ameliorate the inequities present in a student's first experience with research, it is necessary to make these CUREs required introductory courses in which all students must participate. Upper-level elective CUREs can present the same barriers facing students interested in independent research experiences.

\section{CUREs as a Gateway to Undergraduate Independent Research Experiences}

We hope that participation in a CURE would eliminate some of the barriers for students in engaging in undergraduate independent research experiences. Currently, CUREs tend to focus on providing students with opportunities to improve their confidence, self-efficacy, skills, and knowledge about scientific research. However, to be effective in diversifying scientific research, CUREs may also need to explicitly teach students the cultural norms that are important to be successful in applying for and participating in scientific research, thereby enhancing students' cultural capital.

Additionally, student performance in a CURE may also be a more accurate estimate of how well the student will perform in a research environment than the standard criteria, such as GPA or high school experience. Just as faculty members evaluate graduate student candidates primarily on their previous significant research experience, faculty members could evaluate undergraduates on their experience in CUREs, allowing faculty members to more fairly compare student aptitude by using common criteria. Furthermore, well-designed CUREs are likely to improve the quality of all undergraduate researchers, even students who originally would have been hired in independent research experiences, which aligns with faculty members' needs to have highly productive undergraduates in the research lab.

We do not anticipate that, in most cases, participation in CUREs alone would be sufficient for graduate school; students would likely still need to engage in an independent research experience. However, CUREs would provide a gateway for all students to experience the opportunity to engage in research and thus give students a more equal footing when they applied to independent undergraduate research experiences. It could be possible that, at 4-yr institutions that do not offer any independent undergraduate research experiences, CUREs may be the only way for students to get into graduate school.

\section{CONCLUSION}

If undergraduate research experiences are the gateway to graduate school, which is in turn the gateway to becoming a member of the scientific community, then we need to attend to the inequities in undergraduate research if we are to diversify the professoriate. Introductory-level CUREs that are a required part of the curriculum are an ideal model for this, giving all students a more equitable experience in authentic research and providing tools and knowledge about research that can be transferable to other internships. Not only do CUREs give a broader population of students the opportunity to participate in research, but they specifically open the door for the students who may need it the most.

\section{ACKNOWLEDGMENTS}

We thank our funding source, an NSF-funded CUREnet working group small grant. Additionally, we thank J. Collins, C. Carter, S. Eddy, and two anonymous reviewers for helpful suggestions on earlier versions of the manuscript.

\section{REFERENCES}

Adamuti-Trache M, Andres L (2008). Embarking on and persisting in scientific fields of study: cultural capital, gender, and curriculum along the science pipeline. Int J Sci Educ 30, $1557-1584$.

American Association for the Advancement of Science (2011). Vision and Change in Undergraduate Biology Education: A Call to Action. http:/ / visionandchange.org/finalreport (accessed July 2014).

Auchincloss LC, Laursen SL, Branchaw J, Eagan K, Graham M, Hanauer DI, Lawrie G, McLinn CM, Pelaez N, Rowland S, et al. (2014). Assessment of course-based undergraduate research experiences: a meeting report. CBE Life Sci Educ 13, 29-40.

Bertrand M, Mullainathan S (2004). Are Emily and Greg more employable than Lakisha and Jamal? A field experiment on labor market discrimination. Am Econ Rev 94, 991-1013.

Bourdieu P (1986). The forms of capital. In: Handbook of Theory and Research for the Sociology of Education, ed. J Richardson, New York: Greenwood, 241-258.

Boyer EL (1990). Scholarship Reconsidered: Priorities of the Professoriate, Princeton, NJ: Carnegie Foundation for the Advancement of Teaching.

Brownell SE, Kloser MJ, Fukami T, Shavelson RJ (2013). Context matters: volunteer bias, small sample size, and the value of comparison groups in the assessment of research-based undergraduate introductory biology lab courses. J Microbiol Biol Educ 14,176 .

Brownell SE, Tanner KD (2012). Barriers to faculty pedagogical change: lack of training, time, incentives, and ... tensions with professional identity? CBE Life Sci Educ 11, 339-346. 
Carlone HB, Johnson A (2007). Understanding the science experiences of successful women of color: science identity as an analytic lens. J Res Sci Teach 44, 1187-1218.

Chapman DW, Pascarella ET (1983). Predicators of academic and social integration of college students. Res High Educ 19, 295-322.

Cotten SR, Wilson B (2006). Student-faculty interactions: dynamics and determinants. High Educ 51, 487-519.

Cox BE, Orehovec E (2007). Faculty-student interactions outside the classroom: a typology from a residential college. Rev High Educ 30, 343-362.

CUREnet (2012). Pathways over Time. www.curenet.franklin.uga .edu/projects/ pathways-over-time (accessed 25 August 2014).

Desai KV, Gatson SN, Stile TW, Stewart RH, Laine GA, Quick CM (2008). Integrating research and education at research extensive universities with research intensive communities. Adv Physiol Educ 32, 136-141.

Eagan K, Herrera FA, Garibay JC, Hurtado S, Change M (2011b). Becoming STEM proteges: factors predicting the access and development of meaningful faculty-student relationships. Paper presented at the Association for Institutional Research Annual Forum, Toronto, Ontario, Canada, held 24 May 2011.

Eagan MK, Hurtado S, Chang MJ, Garcia GA, Herrera FA, Garibay JC (2013). Making a difference in science education: the impact of undergraduate research programs. Am Educ Res J 50, 683-713.

Eagan MK, Sharkness J, Hurtado S, Mosqueda C, Chang MJ (2011a). Engaging undergraduates in science research: not just about faculty willingness. Res High Educ 52, 151-177.

Espinosa LL (2011). Pipelines and pathways: women of color in undergraduate STEM majors and the college experiences that contribute to persistence. Harvard Educ Rev 81, 209-241.

Harvard University (2013). Division of Medical Sciences Student Qualifications \& Admission Requirements. http://dms.hms .harvard.edu/program/admissions.html (accessed 25August 2014).

Healey M, Jordan F, Pell B, Short C (2010). The research-teaching nexus: a case study of students' awareness, experiences and perceptions of research. Innov Educ Teach Int 47, 235-246.

Hernandez PR, Schultz P, Estrada M, Woodcock A, Chance RC (2013). Sustaining optimal motivation: a longitudinal analysis of interventions to broaden participation of underrepresented students in STEM. J Educ Psychol 105, 89-107.

Hurtado S, Eagan MK, Tran MC, Newman CB, Chang MJ, Velasco P (2011). "We do science here": underrepresented students' interactions with faculty in different college contexts. J Coll Stud Dev 44, 549-565.

Intemann K (2009). Why diversity matters: understanding and applying the diversity component of the National Science Foundation's broader impacts criterion. Social Epistemol 23, 249-266.

Jones MT, Barlow AE, Villarejo M (2010). Importance of undergraduate research for minority persistence and achievement in biology. J High Educ 81, 82-115.

Kim YK, Sax LJ (2009). Student-faculty interaction in research universities: differences by student gender, race, social class, and first-generation status. Res High Educ 50, 437-459.

Kuh GD, Kinzie J, Schuh JH, Whitt EJ, and associates (2005). Student Success in College: Creating Conditions That Matter, San Francisco: Jossey-Bass.

Laursen S, Hunter A-B, Seymour E, Thiry H, Melton G (2010). Undergraduate Research in the Sciences: Engaging Students in Real Science, New York: Jossey-Bass.

Malcom LE, Dowd AC (2012). The impact of undergraduate debt on the graduate school enrollment of STEM baccalaureates. Rev High Educ 35, 265-305.

Meece JL, Glienke BB, Burg S (2006). Gender and motivation. J School Psychol 44, 351-373.
Micari M, Pazos P, Hartmann MJ (2007). A matter of confidence: gender differences in attitudes toward engaging in lab and course work in undergraduate engineering. J Women Minor Sci Eng 13, 281-295.

Milkman KL, Akinola M, Chugh D (2014). What Happens Before? A Field Experiment Exploring How Pay and Representation Differentially Shape Bias on the Pathway into Organizations. http://ssrn .com/abstract $=2063742$. (accessed 11 July 2014).

Moss-Racusin CA, Dovidio JF, Brescoll VL, Graham MJ, Handelsman J (2012). Science faculty's subtle gender biases favor male students. Proc Natl Acad Sci USA 109, 16474-16479.

National Research Council (2003). BIO2010: Transforming Undergraduate Education for Future Research Biologists, Washington, DC: National Academies Press.

National Science Foundation (2013). Women, Minorities, and Persons with Disabilities in Science and Engineering. www.nsf.gov/statistics / wmpd (accessed 25 August 2014).

Ragins BR (1999). Gender and mentoring relationships: a review and research agenda for the next decade. In: Handbook of Gender And Work, ed. G Powell, Thousand Oaks, CA: Sage, 347-370.

Ragins BR, Cotton JL (1993). Gender and willingness to mentor in organizations. J Manage 19, 97-111.

Russell SH, Hancock MP, McCullough J (2007). Benefits of undergraduate research experiences. Science 316, 548-549.

Seymour E, Hewitt N (1997). Talking about Leaving: Why Undergraduates Leave the Sciences, Boulder, CO: Westview.

Seymour E, Hunter AB, Laursen SL, DeAntoni T (2004). Establishing the benefits of research experience for undergraduates in the sciences: first findings from a three-year study. Sci Educ 88, 493-534.

Shehab RL, Murphy TJ, Davidson J, Rhoads TR, Trytten DA, Walden SE (2007). Academic struggles and strategies: how minority students persist. Paper presented at the 2007 American Society for Engineering Education Annual Conference and Exhibition, held June 2007, in Honolulu, HI.

Sikora J, Pokropek A (2012). Gender segregation of adolescent science career plans in 50 countries. Sci Educ 96, 234-264.

Spronken-Smith R, Mirosa R, Darrou M (2013). “Learning is an endless journey for anyone": undergraduate awareness, experiences and perceptions of the research culture in a research-intensive university. High Educ Res Dev 33, 355-371.

Teacher Advisory Council (2012). Community Colleges in the Evolving STEM Education Landscape: Summary of a Summit, Washington, DC: National Academies Press.

Terenzini P, Pascarella E (1978). The relations of students' precollege characteristics and freshman year experience to voluntary attrition. Res High Educ 9, 347-366.

Vianden J (2006). "I don't need any help": what first year college men say about interacting with faculty outside the classroom. Doctoral Dissertation, Bloomington: Indiana University.

Villarejo M, Barlow AE, Kogan D, Veazey BD, Sweeney JK (2008). Encouraging minority undergraduates to choose science careers: career paths survey results. CBE Life Sci Educ 7, 394-409.

Vogt CM (2008). Faculty as a critical juncture in student retention and performance in engineering programs. J Eng Educ 97, 27-36.

Wanberg CR, Welsh ET, Hezlett SA (2003). Mentoring research: a review and dynamic process model. Res Pers Hum Res Manage 21, 39-124.

Webb SA (2007). The Importance of Undergraduate Research. http:/ / sciencecareers.sciencemag.org/career_magazine/previous_ issues/articles/2007_07_06/caredit.a0700095.

Wilson R (2010). Why teaching is not priority no. 1. Chron High Educ, September 5. 